\title{
Characterization and Functions of Vascular Adventitial Fibroblast Subpopulations
}

\author{
Sheng Jun An ${ }^{\mathrm{a}}$ Pei Liu ${ }^{\mathrm{a}}$ Tie Mei Shao ${ }^{\mathrm{a}}$ Zhi Jun Wang ${ }^{\mathrm{a}}$ Hai Gang Lu ${ }^{\mathrm{a}}$ Zhan Jiao \\ Xue Lia Jun Qiu Fu \\ aCenter of Bioreactor and Protein Drug Research and Development of Hebei Universities, Hebei \\ Chemical and Pharmaceutical College, Shijiazhuang, Hebei, ${ }^{\mathrm{b} B e t h u n e ~ M e d i c a l ~ N C O ~ S c h o o l, ~}$ \\ Shijiazhuang, Hebei, China
}

\section{Key Words}

Adventitia • Fibroblast subpopulation • Angiotenson II • Endothelin 1 • Collagen type I

\begin{abstract}
Background: Adventitial fibroblasts have been shown to play an important role in vascular remodeling and contribute to neointimal formation in vascular diseases. However, little is known about adventitial fibroblast subpopulations. This study explored the process of isolating rat thoracic aorta adventitial fibroblast subpopulations and characterized their properties following stimulation with angiotensin II (ANG II), a critical factor involved in cardiovascular diseases such as hypertension. Methods: Adventitial fibroblasts were isolated and cultured from rat aorta. Fibroblast subpopulations were individually expanded using cloning ring techniques. Cells were treated with ANG II $(10 \mathrm{nM}, 100 \mathrm{nM}$ and $1 \mu \mathrm{M})$ for $0.5,1,1.5,3,6$, 12 , or $24 \mathrm{~h}$, and ANG II-induced proliferation and migration were measured by MTT assay and Transwell. Cells were treated with ANG II $(100 \mathrm{nM})$ in the presence or absence of ANG II receptor antagonists $(100 \mu \mathrm{M})$, losartan (for AT1) and PD-123319 (for AT2). PreproET-1 mRNA and ET-1 were determined by RT-PCR and ELISA, respectively. Collagen type I was detected by western blotting. Results: Two major fibroblast subpopulations were found in the adventitia, epithelioid-like cells and spindle-like cells; Although ANG II promotes the growth of both subpopulations, epithelioid-like cell proliferation shows dose-dependency on ANG II from $10 \mathrm{nM}$ to $1 \mu \mathrm{M}$, while proliferation of spindle-like cells reaches a peak value following 100 nM ANG II stimulation; ANG II stimulation enhanced epithelioid-like but not spindle-like cell migration; ANG II dose-dependently increased the expression of preproET-1 and collagen type I, and enhanced ET-1 secretion in epithelioid-like but not spindle-like cells, effects abolished by the AT1 receptor antagonist, but not with AT2 receptor antagonist. Conclusion: Adventitial fibroblasts are heterogeneous and epithelioid-like subpopulations with high sensitivity to ANG II stimulation may be implicated in the pathophysiological mechanisms of vascular remodeling, reparative processes and cardiovascular diseases.
\end{abstract}




\section{Introduction}

The vascular adventitia plays a key role in regulating cardiovascular functions, vascular homeostasis and is also involved in the development of cardiovascular diseases. The homeostasis-maintaining function is fulfilled through the "outside-in" regulation of vascular structure and functions by vascular adventitia fibroblasts as a biological treatment center in response to stress, injuries, cytokines and hormones [1-3]. Various forms of hypertension, atherosclerosis, and vascular injuries are characterized by adventitial fibroblast proliferation, migration and differentiation, and collagen deposition [4, 5]. Previous studies examined only a few of the many known fibroblast characteristics. For example, fibroblasts of lung tissue were shown to be heterogenous with regard to morphology $[6,7]$, proliferative capacity [7, 8], and surface marker expression [7, 9]. However, it has not yet been reported whether the thoracic aortic adventitial fibroblasts of SD rats are composed of heterogenous fibroblast subpopulations with unique functional characteristics.

The role of angiotensin II (ANG II) in the development of hypertension and atherosclerosis is well accepted [10]. In addition, it is known that ANG II participates in the pathogenesis of cardiovascular and renal diseases through regulation of cell growth, inflammation or fibrosis $[11,12]$. In cultured adventitial fibroblasts, ANG II stimulates the proliferation $[13,14]$ and migration of the adventitial fibroblasts $[14,15]$, and the formation of myofibroblast $[14,16]$. It is well known that ANG II stimulates collagen production in various fibroblasts. Moreover, local production of Endothelin-1(ET-1) within the adventitia after ANG II treatment has been recently reported [17]. However, little is known regarding the effects of ANG II on the fibroblast subpopulations and the underlying mechanisms.

In view of these considerations, we sought to determine whether adventitial fibroblasts of SD rats were composed of heterogenous subpopulations as well as the effects of ANG II on the fibroblast subpopulations. The present study demonstrated that fibroblasts could be described morphologically as mainly having two shapes, epithelioid-like and spindle-like. Furthermore, ANG II receptor antagonists had different effects on the cell subpopulations. The characterization of the fibroblast subpopulations and the effects of ANG II on the subpopulations suggest that the two cell subpopulations are involved in distinct roles in regards to vascular remodeling and the reparative processes.

\section{Materials and Methods}

Isolation and Culture of SD Rat Thoracic Aorta Adventitial Fibroblast Subpopulations

Male SD rats, 6-8 wks. of age, were obtained from the Experimental Animal Center of Hebei Medical University. The rats were anesthetized with inhaled isoflurane and then killed by vertebral dislocation. After their thoracic aortas were removed and cleaned under sterile conditions, media was separated from the adventitia and then the isolated adventitia was rinsed three times with PBS, cut into 1- to 2- $\mathrm{mm}^{2}$ flat segments and planted on dishes. Fresh medium consisting of DMEM and F-12 nutrient mixture (DMEM/F-12; Invitrogen, Auckland, NZ) supplemented with 20\% FBS (BioWhittaker, Lonza, Belgium) and 100×Antibiotic Antimycotic Solution (Sigma-aldrich, USA), was added into each dish. The explants were incubated in a humidified incubator at $37^{\circ} \mathrm{C}$ in a $95 \%$ air- $5 \% \mathrm{CO}_{2}$ atmosphere until the cells reached confluence, typically 4- 6 days. From the third day onward, the culture medium was removed and replaced with fresh medium every $48 \mathrm{~h}$. Confluent cells were subsequently harvested for passage with a trypsin $(0.25 \%)$ solution (Sigmaaldrich). Using a hemocytometer, the cells were counted and this cell suspension were diluted with the media containing DMEM/F-12 and 20\% FBS. Single cells were plated at density of 10-50 cells in $100 \mathrm{~mm}$ dishes. After the cells got adhered, culture medium was replaced and a marker pen was used to mark the single cells. Subpopulations were individually expanded using cloning ring and trypsinization techniques. When the cells had grown to confluence, they were transferred serially into 24- and 6-well culture dishes. In all experiments, fibroblast subpopulations of the 3rd and 4th passages were studied. All animal protocols were approved and conducted according to the recommendations from the Research Sub-Committee of Hebei Medical University on Animal Care and Use and the Chinese Council on Animal Care. 
Cell Treatment

Cells growing to subconfluence were incubated in serum-free medium for $24 \mathrm{~h}$. Cells were treated with ANG II at $10 \mathrm{nM}, 100 \mathrm{nM}$ and $1 \mu \mathrm{M}$ for $0.5,1,1.5,3,6,12$, or $24 \mathrm{~h}$. The cells were then collected for RNA isolation. For protein detection, they were preincubated with losartan (100 $\mu \mathrm{M}$, Sigma-aldrich) [17, 18], an ANG II type 1 (AT1) receptor antagonist, and PD-123319 (100 $\mu$ M, Sigma-aldrich) [17, 18], an ANG II type 2 (AT2) receptor antagonist, for $30 \mathrm{~min}$, and then incubated with or without ANG II (100 $\mathrm{nM}$ ) in the presence of the inhibitor. ET-1 peptide in the cell culture medium was determined via ELISA, and Western blot analysis was used for measurement of collagen type I protein in whole cell lysates.

\section{Characterization of Isolated Cells by Immunocytochemistry and RT-PCR}

To demonstrate that the cultured cells were not contaminated by endothelial cells, vascular smooth muscle cells or leukocytes, the cultured cells for specific cell markers were characterized by means of immunocytochemistry and/or RT-PCR. For immunohistochemical study, the cultured cells were stained with one of the following antibodies: anti-mouse von Willebrand factor (vWF; 1:500, $1 \mathrm{~h}$. at room temperature; GeneTex, USA) as a marker for endothelial cells; anti-rabbit desmin (1:20, $1 \mathrm{~h}$. at room temperature; Epitomics, USA), a marker for differentiated vascular smooth muscle cells; and anti-rabbit vimentin (1:100, $1 \mathrm{~h}$. at room temperature; Epitomics), a nonspecific marker for many cell types.

For RT-PCR study, total RNA was extracted from adventitial fibroblast subpopulations or from intact aortas by the use of Trizol (Invitrogen, New Zealand, USA). For the reverse transcription stage, $1 \mu \mathrm{g}$ of total RNA, treated with DNase I, was reversely transcribed in the presence of a random primer and reverse transcriptase. For PCR, the synthesized cDNA was amplified by PCR, using an Agilent Stratagene thermal cycler (Agilent, USA) with 1.25 units of Taq polymerase (Biomed, Beijing, China), $20 \mathrm{mM}$ Tris- $\mathrm{HCl}$ (pH 8.0), $50 \mathrm{mM} \mathrm{KCl}, 0.2 \mathrm{mM} \mathrm{dNTP}, 1.5 \mathrm{mM} \mathrm{MgCl}_{2}$, and $0.02 \mu \mathrm{M}$ each of the gene-specific oligonucleotide primers shown in Table 1 . The cyclic program was as follows: Initial denaturization at $95^{\circ} \mathrm{C}$ for 5 min, denaturization at $95^{\circ} \mathrm{C}$ for $1 \mathrm{~min}$, annealing at $(48-52)^{\circ} \mathrm{C}$ for $1 \mathrm{~min} 30 \mathrm{sec}$, extension at $72^{\circ} \mathrm{C}$ for $1 \mathrm{~min}$, and a last cycle at $72^{\circ} \mathrm{C}$ for $10 \mathrm{~min}$. The amplifications were carried out for 30 cycles. PCR products were electrophoresed on $1.2 \%$ agarose gel and stained with ethidium bromide. The amplified DNA from the adventitial fibroblast epithelioid-like cell (also named round cell) culture, spindle-like cell (also named spindle cell) culture and the aorta were characterized and compared for cell markers of endothelial cells (von Willebrand factor), vascular smooth muscle cells (myosin heavy chain and desmin), and leukocytes (CD8). The housekeeping gene $\beta$-actin was used as a positive control.

\section{Sizes of Fibroblast Subpopulations}

The cells were harvested with a trypsin $(0.25 \%)$ solution, centrifuged at a low speed for $5 \mathrm{~min}$, and rinsed with normal sodium (Shijiazhuang, Hebei, China). The cells were then added to $0.5 \mathrm{ml}$ of normal sodium, and then their size was measured with Epics-X II flow cytometry (Beckman Coulter, USA) according to the protocol in the Research Center of the Fourth Hospital of Hebei Medical University (Shijiazhuang, Hebei, China).

\section{Growth of Fibroblast Subpopulations}

To examine the in vitro growth characteristics of fibroblast subpopulations, serum-stimulated growth was measured by MTT assay (Solarbio, Beijing, China). Cells were sparsely seeded $\left(1.0 \times 10^{4}\right.$ cells/well) in DMEM/F-12 containing 10\% FBS in 96-well plates, and cell counts were performed everyday between day 1 and day 7. Media were supplemented but not replaced with fresh media containing 10\% FBS on day 4 to avoid blunting the growth of more rapidly proliferating cells. $20 \mu \mathrm{l}$ MTT solutions $(5 \mathrm{mg} / \mathrm{ml})$ was added to each group and then incubated for $4 \mathrm{~h}$, followed by the removal of the culture medium, and the replacement with DMSO $200 \mu \mathrm{l} /$ well (Sigma-aldrich). The 96-well plates were oscillated for $10 \mathrm{~min}$, and then absorbance values were determined by enzyme immunoassay instruments (ThermoFisher, Finland). The cell growth curve was drawn with time as abscissa and absorbance as ordinate.

\section{ANG II-Induced Proliferation}

Cells were treated with ANG II at $10 \mathrm{nM}, 100 \mathrm{nM}$ and $1 \mu \mathrm{M}$ for $72 \mathrm{~h}$, and the cell proliferation was detected by MTT assay as described above.

\section{KARGER}


Table 1. Sequences for primers. *: von Willebrand factor; $\uparrow$ : myosin heavy chain

\begin{tabular}{|c|c|c|c|c|}
\hline Gene name & Primer se & uence & Annealing temperature & Product \\
\hline $\mathrm{vWF}^{*}$ & $\begin{array}{l}\text { Forward } \\
\text { Reverse }\end{array}$ & $\begin{array}{l}5^{\prime} \text {-TGTTCCAGATCTTTGGCA-3' } \\
5^{\prime} \text {-TCTGTTTGATTGGCGTGC-3' }\end{array}$ & $52^{\circ} \mathrm{C}$ & $358 \mathrm{bp}$ \\
\hline $\mathrm{MHC}^{+}$ & $\begin{array}{l}\text { Forward } \\
\text { Reverse }\end{array}$ & $\begin{array}{l}\text { 5'-AAAGGGCATGTTCCGCAC-3' } \\
5^{\prime} \text {-CGCAGCTGCTCCAGAACTAG-3' }\end{array}$ & $51^{\circ} \mathrm{C}$ & $696 \mathrm{bp}$ \\
\hline CD8 & $\begin{array}{l}\text { Forward } \\
\text { Reverse }\end{array}$ & $\begin{array}{l}5^{\prime} \text {-TCTCCGGTCTGCCCATCATA-3' } \\
5^{\prime} \text {-TGCTCCCTGTGGTTGAGG-3' }\end{array}$ & $54^{\circ} \mathrm{C}$ & $691 b p$ \\
\hline desmin & $\begin{array}{l}\text { Forward } \\
\text { Reverse }\end{array}$ & $\begin{array}{l}\text { 5'-TCCTTAAGAAAGTGCACGAA-3' } \\
5^{\prime} \text {-TGAAACCTTGGACTTGTACC- } 3^{\prime}\end{array}$ & $52^{\circ} \mathrm{C}$ & $696 \mathrm{bp}$ \\
\hline preproET-1 & $\begin{array}{l}\text { Forward } \\
\text { Reverse }\end{array}$ & $\begin{array}{l}5^{\prime} \text {-GCTCCTCCTTGATGGACAA-3' } \\
5^{\prime} \text {-TTTGGTGAGCACACTGGC-3' }\end{array}$ & $48^{\circ} \mathrm{C}$ & $182 \mathrm{bp}$ \\
\hline$\beta$-actin & $\begin{array}{l}\text { Forward } \\
\text { Reverse }\end{array}$ & $\begin{array}{l}\text { 5'-ATATCGCTGCGCTCGTCGT-3' } \\
5^{\prime} \text {-TCTCTTGCTCTGGGCCTCGT-3' }\end{array}$ & $(48-58)^{\circ} \mathrm{C}$ & $175 \mathrm{bp}$ \\
\hline
\end{tabular}

ANG II-Induced Migration

Cells were sparsely seeded $\left(1.0 \times 10^{4}\right.$ cells/well) in each insert of transwell (24 Well Millicell, Millipore, EU), and $0.5 \mathrm{ml}$ medium containing $100 \mathrm{nM}$ of ANG II was then added to the lower chamber (24 Well culture plate, Sigma). The protocols were conducted according to the instructions, and some modifications were made, and then the operation was carried out. The plate was covered and incubated for $0,0.5,1,1.5$, or $12 \mathrm{~h}$. By pipetting out the remaining cell suspension, the cells/media were carefully removed from the top side of the insert. The migration insert was placed into a clean well containing $95 \%$ ethanol incubate for 20 min at room temperature before the insert was dipped into a beaker full of water several times, then the migration insert was placed into a clean well containing $400 \mu \mathrm{l}$ of $0.1 \%$ of liquid dye crystal violet (Yongda, Tianjin, China). After the insert was incubated for $20 \mathrm{~min}$ at room temperature, the insert was dipped into a water beaker several times to rinse, and then it was examined under the microscope. The stained insert was transferred to a clean well containing 33\% of acetic acid for $5 \mathrm{~min}$ at room temperature. At last, the Optical Density (OD) was measured with multifunctional detector at $560 \mathrm{~nm}$. This experiment was repeated for three times.

Qualitative and Relative Quantification of preproET-1 mRNA by RT-PCR

The procedures of total RNA extraction, reverse transcription and PCR were described previously. The primer sequences for preproET-1 are listed in Table 1.

Measurement of ET-1 Peptide Levels by ELISA

The cell culture medium was collected for ET-1 ELISA measurement. The concentration of ET-1 in culture medium was determined by using a commercial ELISA kit (Cusabio, Hubei, China) according to the manufacturer's instructions. The ET- 1 release was expressed as fM of ET-1 per $10^{5}$ cells.

Measurement of Collagen Type I Expression by Western Blot Analysis

Cells were cultured with or without different treatments for $24 \mathrm{~h}$. and lysed with RIPA lysis buffer (BestBio, Shanghai, China) containing 50 mM HEPES (pH 7.5), $100 \mathrm{mM} \mathrm{NaCl}, 1 \%$ Triton, $2.5 \mathrm{mM}$ $\beta$-glycerophosphate, $10 \%$ glycerol, $5 \mathrm{mM} \mathrm{MgCl}$, 1 mM EGTA, $50 \mathrm{mM} \mathrm{NaF}, 1 \mathrm{mM}$ sodium orthovanadate, $10 \mu \mathrm{g} /$ $\mathrm{ml}$ leupeptin, $10 \mu \mathrm{g} / \mathrm{ml}$ aprotinin, and $1 \mathrm{mM}$ phenylmethylsulfonyl fluoride. Equal amounts of total proteins $(20 \mu \mathrm{g} /$ well) were separated by electrophoresis in SDS-PAGE under reducing conditions and transferred to a PVDF membrane (Millipore). Collagen type I (Abcam, HongKong, China) was detected by incubating the membranes with polyclonal antibody against collagen type I $(1: 2000)$ overnight at $4^{\circ} \mathrm{C}$. The membranes were then incubated with the secondary peroxidase-conjugated antibody (1:2000) and detected by the ECL kit (MultiSciences, Beijing, China) according to manufacturer's instructions.

Data analysis

Results were expressed as means \pm SD. Each observation was reproduced in the cells isolated from at least three different animals. Statistical comparisons were made using Two-way ANOVA. Differences of $P<$ 0.05 were considered significant. 


\section{Results}

\section{Isolation of purified Fibroblast Subpopulations}

Cloning ring technique was utilized to determine that clones, or at least highly purified primary fibroblast subpopulations, could be derived from the thoracic aortic adventitia. Aggregate fibroblast populations were enzymatically dispersed from the cleaned adventitia and suspended in media. When single cells were transformed into a clone colony, cloning ring and trypsinization techniques allowed for expansion, providing sufficient means for biochemical and functional characterization. Thus, the cloning ring technique could be used to establish purified primary fibroblast subpopulations from the thoracic aortic adventitia of the SD rats.

It was determined by analyzing the fibroblast subpopulations derived from each animal that the thoracic aortic adventitia of the SD rats, like other fibroblast-enriched tissues $[6,9$, 13-15], was composed of multiple morphologically, biochemically, and functionally distinct populations. When examined by an inverted phase contrast microscope, the cells in the $\geq 120$ subpopulations that were evaluated could be described as having two general morphologies, one appearing elongated or spindle shaped (Fig. 1Ai, named spindle cell) and the other more rounded or epithelioid in shape (Fig. 1Aii, named round cell). Within these two broad classifications, there were differences among subpopulations in characteristics such as cell

Fig. 1. Cell purity identification of fibroblast subpopulations. A. fibroblast subpopulations derived from the adventitial fibroblasts demonstrate an epithelioid appearance, named round cell (Aii), and another appears a spindle shape, named spindle cell (Ai). B. Immunofluorescence stains of fibroblasts are shown for desmin, a marker for vascular smooth muscle cells (Bi), vWF, a marker for endothelial cells (Bii), and vimentin, a nonspecific marker for many cell types (Biii). The nucleoli were stained by DAPI. There is no dense staining for desmin and vWF, but strong staining for vimentin in SD rat aortic adventitial cells. C. Cell purity identification by RT-PCR. SC: spindle cell;

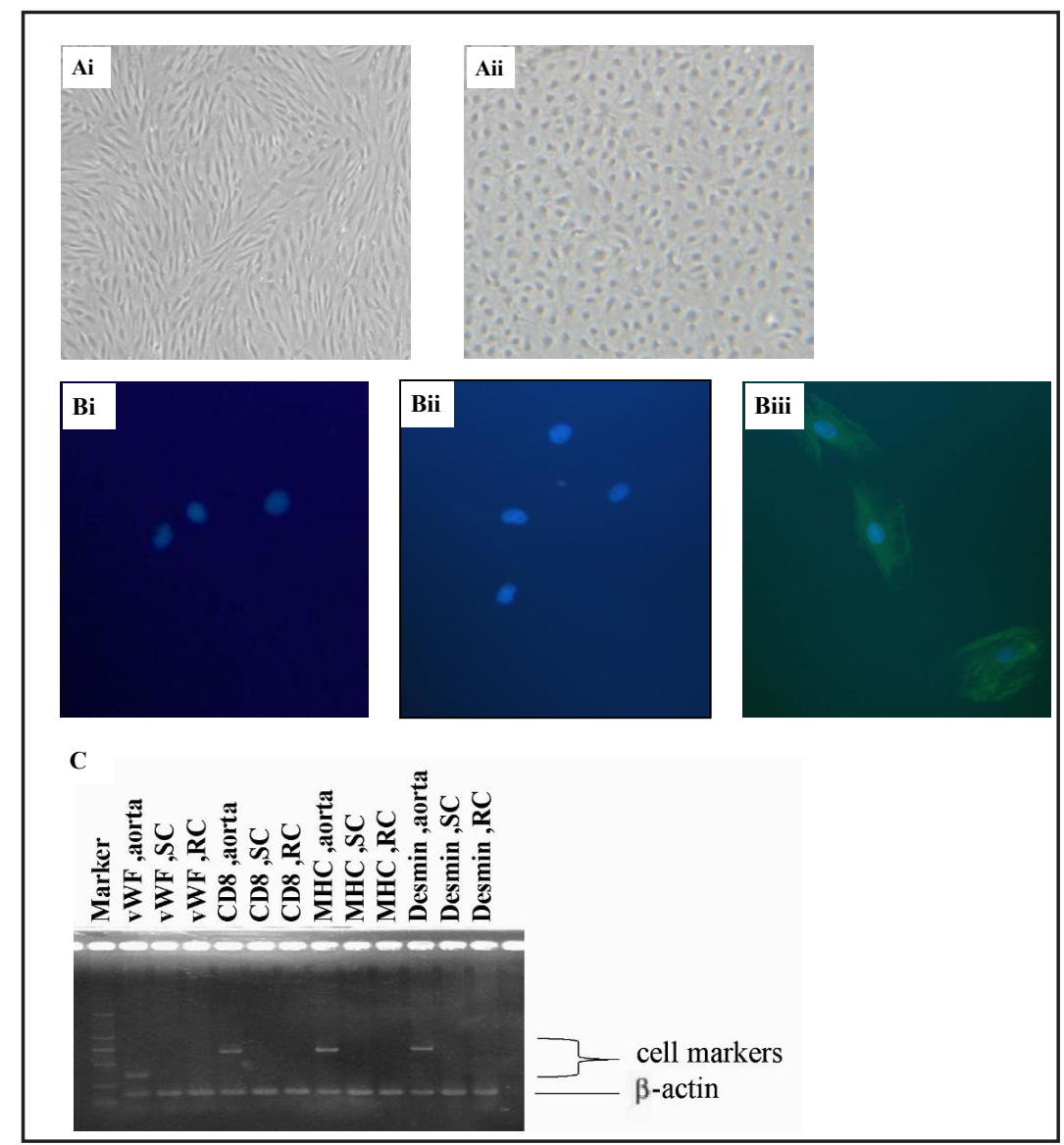

RC: Round cell. Round cells and spindle cells derived from the adventitia of the aorta shows no expression for vWF (endothelial cell marker), CD8 (leukocytes marker), desmin and MHC (vascular smooth muscle cell marker). In contrast, the aorta has strong positive staining for vWF, CD8, MHC and desmin. Both cultured fibroblast subpopulations and aorta tissue expresses $\beta$-actin (housekeeping gene). Each photograph is a representative example of the 3 experiments from 3 SD rats. 
$\mathbf{A i}$

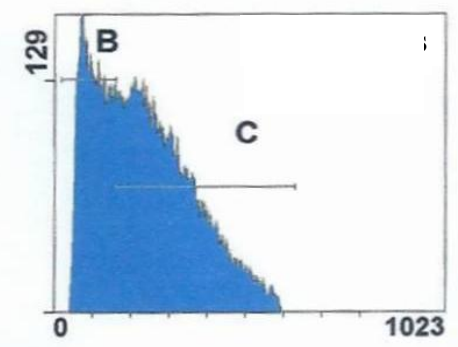

FS

(F1)[A] G0113705.LMD : FS Region Number \%Gated X-Mean X-Mode \begin{tabular}{llllll} 
Region & Number & $\%$ Gated & X-Mean & X-Mod \\
B & 11931 & 34.05 & 103.1 & 71.0 \\
\hline
\end{tabular} $\begin{array}{lllll}\text { B } & 11931 & 34.05 & 103.1 & 71.0 \\ \text { C } & 23105 & 65.95 & 305.1 & 200.0\end{array}$
Aii

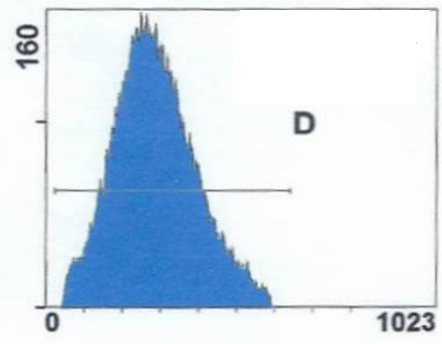

FS

(F2)[A] G0113706.LMD : FS

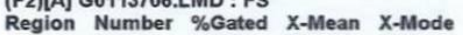

$\begin{array}{lllll}\text { Region } & \text { Number } & \% \text { Gated } & \text { X-Mean } & \text { X-Mode } \\ \text { D } & 40258 & 100.00 & 285.7 & 247.0\end{array}$
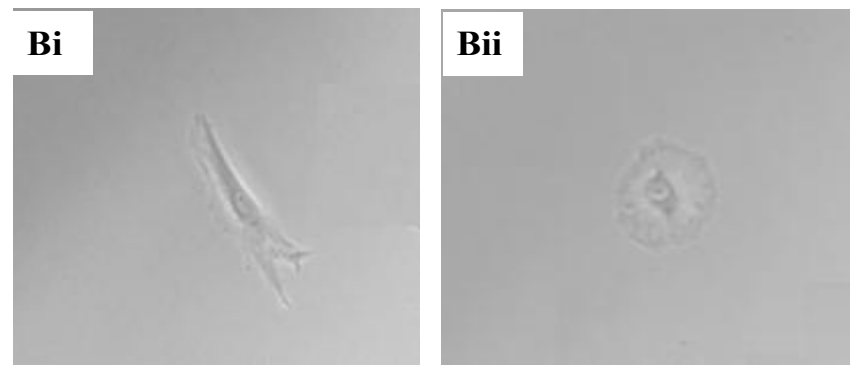

Fig. 2. Cell sizes detected by a flow cytometry(A) and inverted phase contrast microscope(B). Ai, Bi. Spindle cells, Aii, Bii. Round cells. Spindle cells had two diameters while round cells had only one.

Fig. 3. Cell proliferation of spindle cells and round cells. A. Serum-stimulated growth of two cells. the exponential phase of growth in round cells is from the 2 nd to the 4 th day after passage; and for spindle cells, the exponential phase of growth is from the 3rd to the 5th day after passage. B. Effects of ANG II at $10 \mathrm{nM}, 100 \mathrm{nM}$ and $1 \mu \mathrm{M}$ for $72 \mathrm{~h}$ on proliferation, we can see that the growth of the two cells have different trends. ${ }^{* *} P<0.01$ vs respective control group.

size (Fig. 2), pattern of organization (i.e., whorl vs. linear), and shape (Fig. 1A). These morphological findings support the idea that the thoracic aortic adventitia is composed of a mixed population of fibroblasts in SD rats.

\section{Characterization of Vascular Adventitial Fibroblast Subpopulations}

Under the microscope, adventitial fibroblasts derived from the explants displayed a smooth cell border and spindlelike bipolar and tripolar morphology. Each pole presented a small process. After

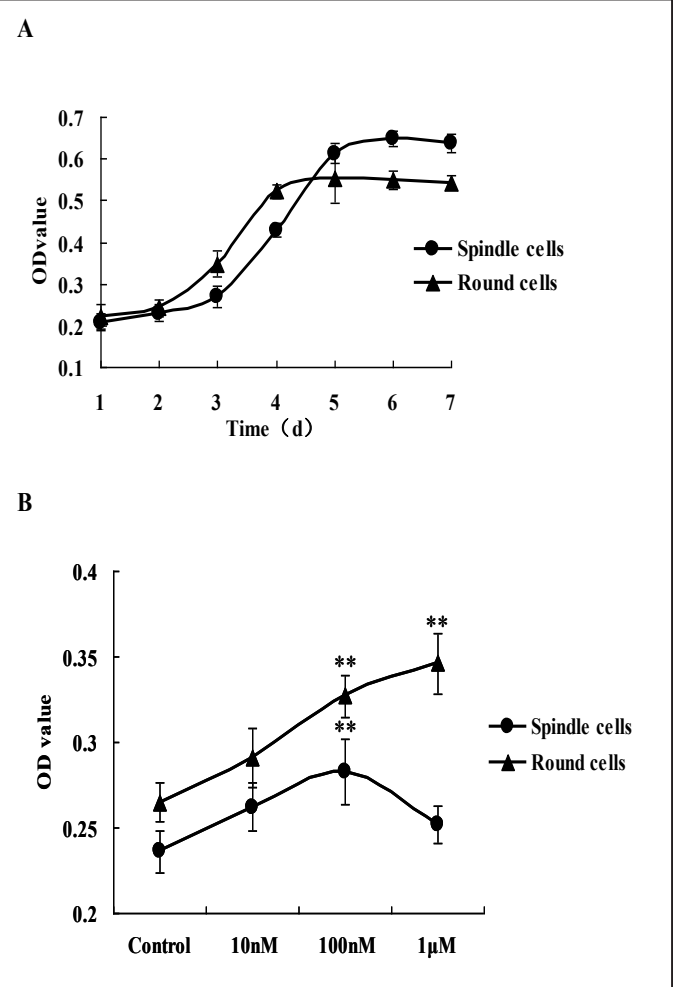


Fig. 4. Effects of ANG II on migration in spindle cells and round cells. The cells are incubated with ANG II at various concentrations (10 and $100 \mathrm{nM}, 1 \mu \mathrm{M}$ ) for 2 h. A. Crystal violet staining. B. Control with spindle cells, ANG II (100 nM and $1 \mu \mathrm{M})$ significantly increased migration of round cells. Results are means \pm SD of 3 experiments. ${ }^{*} P<$ $0.05,{ }^{*} P<0.01$ vs respective control cells.

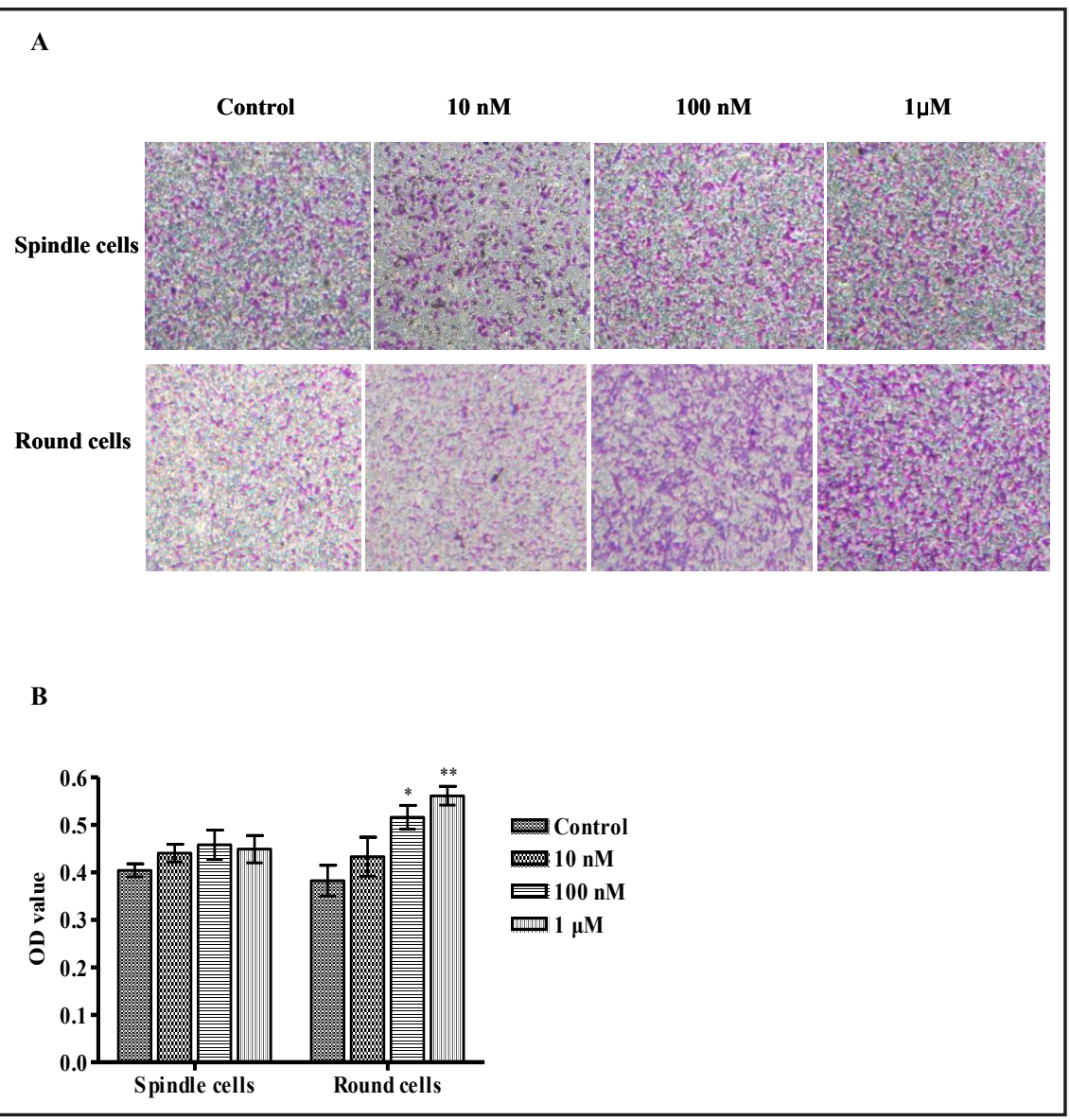

confluence, these cells displayed a multilayer phenotype. Immunocytochemical analysis of the cultured cells derived from the adventitia showed no staining for desmin (Fig. 1Bi) and vWF (Fig. 1Bii). In contrast, all cells had strong positive staining for vimentin (Fig. 1Biii). These results indicated that the cell culture contained primarily fibroblasts with little or no contamination from endothelial and smooth muscle cells, thus the fibroblast subpopulations were pure clones.

Characterization of mRNA of various cell markers in cultured fibroblast subpopulations by RT-PCR is shown in Fig. 1C. The cultured cells derived from the adventitia of the aorta did not show any expression for $\mathrm{VWF}, \mathrm{CD} 8, \mathrm{MHC}$, and desmin. In contrast, the aorta had strong positive staining for vWF, CD8, MHC, and desmin. Both cultured fibroblasts and aorta tissues expressed $\beta$-actin.

\section{Sizes of Fibroblast Subpopulations}

It was observed by Epics-X II flow cytometry in size comparison between the two subpopulations that spindle cells had two spikes and round cells had one spike. In other words, spindle cells had two diameters while round cells had only one. This result was consistent with what was observed under an inverted microscope (Fig. 2).

\section{Growth of Fibroblast Subpopulations}

The MTT method can accurately reflect the number of viable cells and objectively reflect cell proliferation. Growth curves were generated for the two fibroblast subpopulations isolated from the adventitia of SD rats, which shows that the isolated fibroblast subpopulations exhibit differences in growth capability. Marked differences in growth capacity in the presence of $10 \%$ serum-containing media were noted between the subpopulations (Fig. 
Fig. 5. Effects of ANG II on expression of preproET-1 in spindle cells and round cells. A. Cells were incubated with ANG II (100 $\mathrm{nM})$ for various times. Maximal stimulation was detected after $30 \mathrm{~min}$ of incubation. B. The cells were incubated with ANG II $(0,10 \mathrm{nM}, 100 \mathrm{nM}$, and $1 \mu \mathrm{M}$ ) for $30 \mathrm{~min}$. Results are means \pm SD of 3 experiments. ${ }^{* *} P<0.01$ vs respective control cells.

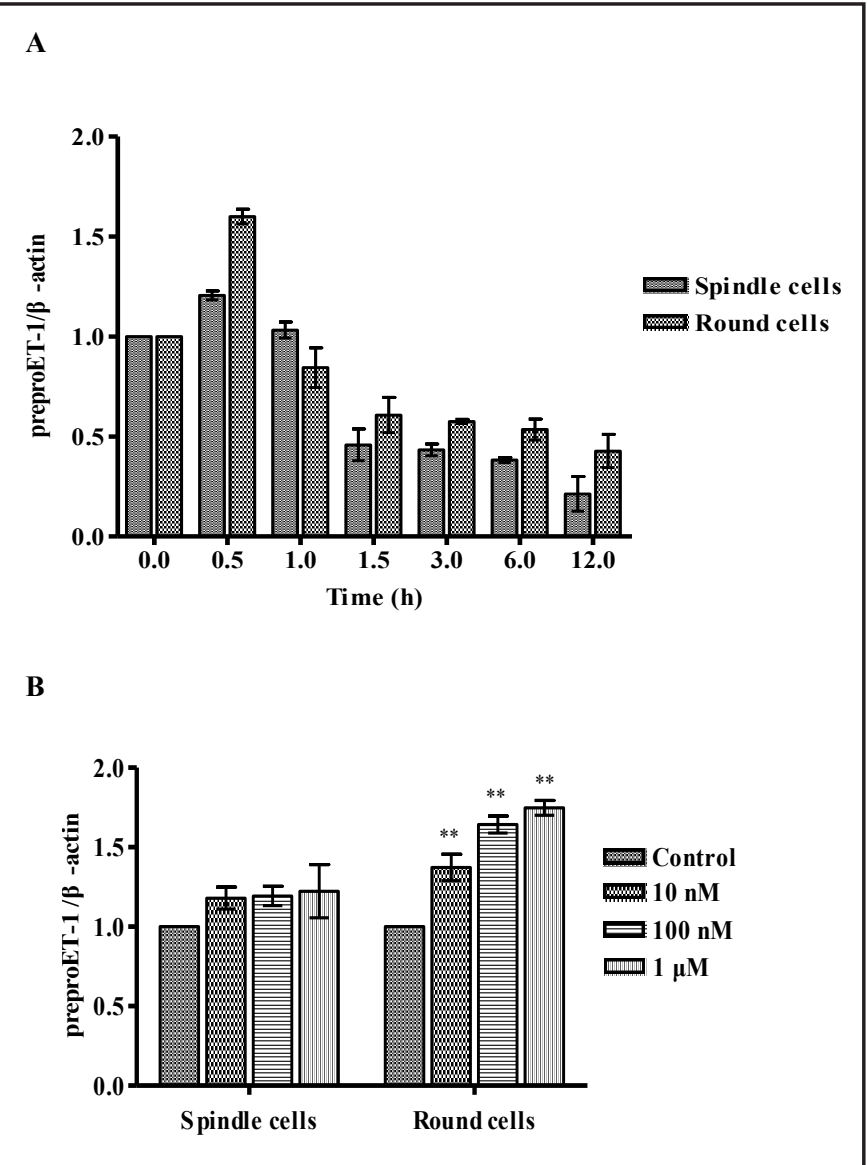

$3 \mathrm{~A}$ ). Round cells proceeded into an index dividing phase on the 2 nd day, while spindle cells proceeded into an index dividing phase on the 3rd day.

\section{ANG II-Induced Proliferation of Fibroblast Subpopulations}

Fig. 3B shows that, compared with respective control group, ANG II (10 and $100 \mathrm{nM}, 1$ $\mu \mathrm{M}$ ) has a different response to cell proliferation between the two subpopulations. ANG II (1 $\mu \mathrm{M})$ can increase the proliferation of round cells significantly $(30.5 \%, P<0.01)$.

\section{ANG II-Induced Migration of Fibroblast Subpopulations}

ANG II (100 $\mathrm{nM})$ induction of cell migration in various time periods after treatment was time-dependent, $\mathrm{T}=2 \mathrm{~h}$., cell migration of spindle cells and round cells did not have a statistically significant difference (data not shown). In a further comparison of the effects of various ANG II concentrations on migration, $T=2 \mathrm{~h}$. was selected to observe the result. The data demonstrated that ANG II $(100 \mathrm{nM}$ and $1 \mu \mathrm{M})$ significantly increased migration of round cells, but no obvious influence on the migration of spindle cells was observed (Fig. 4).

\section{ANG II-Induced Expression of PreproET-1 mRNA}

The effects of incubation time with ANG II on the expression of preproET-1 mRNA in cultured fibroblast subpopulations are presented in Fig. 5A. The expression of preproET-1 mRNA reached a maximum at the $0.5 \mathrm{~h}$ mark $(P<0.05)$ after incubation with ANG II $(100$ $\mathrm{nM}$ ). Thereafter, preproET-1 mRNA expression decreased progressively.

The effects of various concentrations of ANG II on the expression of preproET-1 mRNA in cultured fibroblast subpopulations are displayed in Fig. 5B. The cells were incubated in the presence and absence of ANG II (10 and $100 \mathrm{nM}, 1 \mu \mathrm{M})$ for $30 \mathrm{~min}$. In the absence of ANG II, preproET-1 mRNA expression of the two subpopulations was detectable but low. In 
Fig. 6. Effects of ANG II receptor inhibitors on ANG II-induced expression of preproET-1 (A) and release of ET-1 peptide (B) in spindle cells and round cells. Con: control, Los: Losartan, PD: PD123319. The cells were preincubated with Losartan $(100 \mu \mathrm{M})$, an $\mathrm{AT}_{1}$ receptor antagonist, and $\mathrm{PD}$ $123319(100 \mu \mathrm{M})$, an $\mathrm{AT}_{2}$ receptor antagonist for $30 \mathrm{~min}$. The cells were then incubated with or without ANG II (100 nM) for $30 \mathrm{~min}$ (A) or $24 \mathrm{~h}$ (B) in the presence of the inhibitor. Results are means \pm SD of 3 experiments. ${ }^{* *} P<0.01$ vs respective control cells.
A

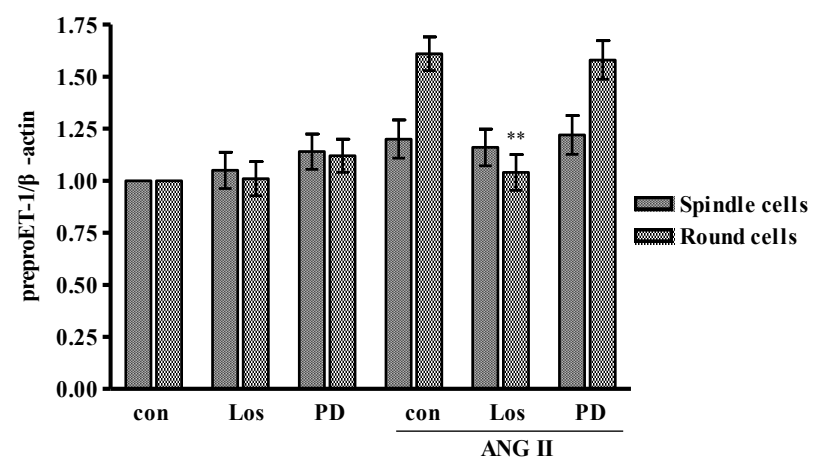

B

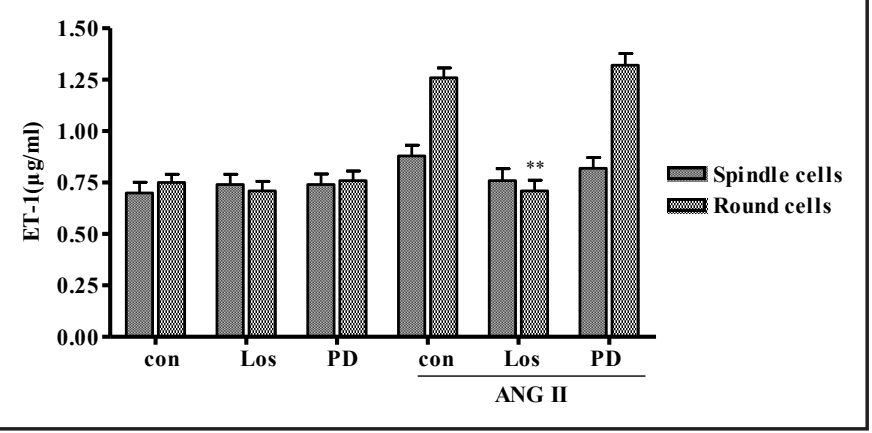

contrast, the addition of ANG II evoked a concentration-dependent increase in preproET-1 mRNA expression. The preproET-1 mRNA expression was significantly different in round cells $(P<0.01)$ and no significant difference was observed with spindle cells $(P>0.05)$.

Figure 6A shows the effects of ANG II receptor antagonists on the increase in preproET-1 mRNA expression evoked by ANG II. In round cells, pretreatment with the AT1 receptor antagonist losartan $(100 \mu \mathrm{M})$, but not the AT2 receptor antagonist PD-123319 $(100 \mu \mathrm{M})$, blocked the elevations in preproET-1 mRNA evoked by ANG II. In spindle cells, neither losartan nor PD-123319 had a significant effect on preproET-1 mRNA. Neither antagonist affected preproET-1 mRNA expression in the absence of ANG II. These data suggest that the induction of the expression of preproET-1 mRNA by ANG II is mediated by AT1 receptors in round cells.

\section{Effects of ANG II on ET-1 Release}

Figure $6 \mathrm{~B}$ presents the effects of ANG II receptor antagonists on ET-1 release. In round cells, the ANG II-evoked increases in ET-1 release were blocked by losartan $(100 \mu \mathrm{M})$ but not by PD-123319 $(100 \mu \mathrm{M})$. In spindle cells, losartan and PD-123319 did not have a significant effect on ET-1 release. Neither antagonist affected ET-1 levels in the absence of ANG II.

\section{ANG II- Induced Expression of Collagen Type I Protein}

The expression of collagen type I protein in fibroblast subpopulations is showed in Fig. 7. ANG II (100 nM) did not have a significant effect on collagen type I protein expression in spindle cells, but caused a significant increase in round cells. The expression of collagen type I protein in round cells which were preincubated with Losartan $(100 \mu \mathrm{M})$ and then incubated with ANG II (100 nM) for $30 \mathrm{~min}$ in the presence of the inhibitor was inhibited by the $\mathrm{AT}_{1}$ receptor antagonist, Losartan, but not by $\mathrm{AT}_{2}$ receptor antagonist, PD-123319. 


\section{$\mathbf{A i}$}

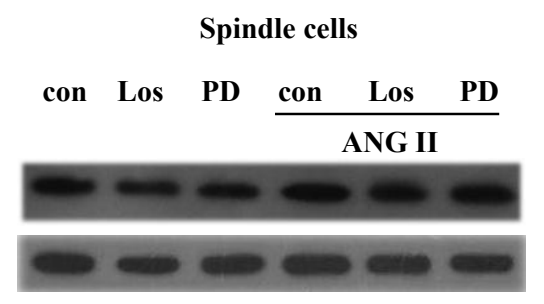

collagen type I

$\beta$-actin

Bi

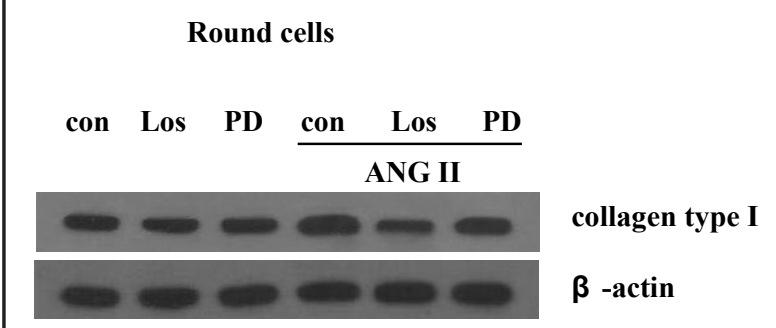

Aii

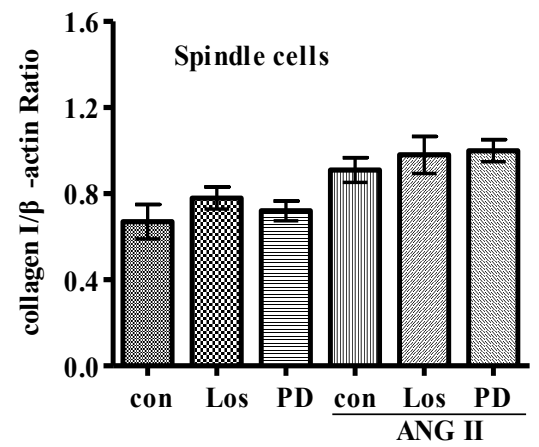

Bii

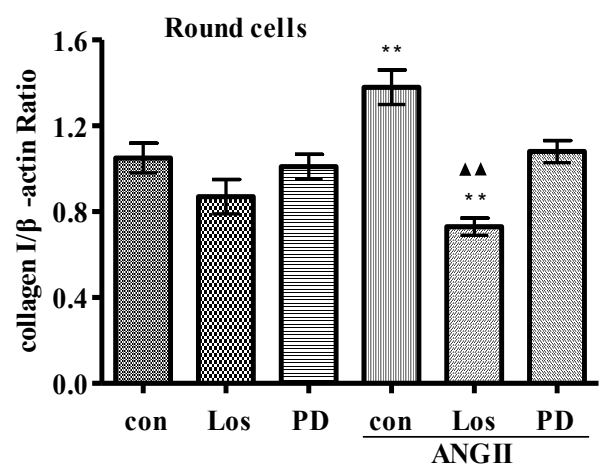

Fig. 7. Effects of ANG II and its receptor inhibitors on the expression of collagen type I protein synthesis. The cells were preincubated with losartan $(100 \mu \mathrm{M})$, an AT1 receptor antagonist, PD-123319 (100 $\mu \mathrm{M})$, an AT2 receptor antagonist for $30 \mathrm{~min}$. The cells were then incubated with or without ANG II (100 nM) for $24 \mathrm{~h}$ in the presence of the inhibitors. Ai, Bi. a representative blot of type I collagen protein levels detected by Western blot. Aii, Bii. pretreatment with losartan, but not with PD-123319, inhibited the induction of collagen type I, suggesting the induction was AT1 receptor-mediated in round cells. The results are means \pm SE of 4 experiments. ${ }^{* *} P<0.01$ vs respective control group, ${ }^{\wedge}{ }^{\wedge} P<0.01$ vs respective ANG II group.

\section{Discussion}

In this study, the main findings were that the adventitia of SD rats were composed of numerous phenotypically distinct subpopulations of fibroblasts. Under a microscope, fibroblast subpopulations derived from the explants displayed a smooth cell border and spindle-like bipolar morphology, namely round cell and spindle cell and the two subpopulations had significant differences in response to external factors, such as serum and ANG II. Extensive literature demonstrates fibroblast heterogeneity in other tissues $[6,7$, $9,19,20-23]$; it is perhaps not surprising that fibroblast heterogeneity in the thoracic aortic adventitia of SD rat would be proved in this study. However, there were differences between the subpopulations in such aspects as morphology, the size of cells, the serum-stimulated growth, the ANG II-stimulated cell proliferation and migration, and the expression of ET-1 and collagen I protein. 
The present study has examined various characteristics of the fibroblast. Differences are observed in the characteristics of the subpopulations of skin fibroblasts and pulmonary artery adventitial fibroblasts derived from several animals. More importantly, the growth rate pattern of the heterogenous subpopulations obtained from one animal has a striking resemblance to the subpopulations derived from other animals, indicating that the observed heterogeneity is a consistent and true characteristic of the fibroblast subpopulations of SD rat adventitia [19-22, 24-26].

Our previous studies demonstrated for the first time that adventitial fibroblasts synthesize and release ET-1 after stimulation by ANG II and that the released ET-1 is biologically active [17]. In the current study, ANG II significantly increases the expression of preproET-1 mRNA and protein in round cells in a concentration- and time-dependent manner, and has no significant effect on the expression of preproET-1 mRNA and protein in spindle cells. The ANG II-evoked increases in ET-1 synthesis and release appear to be mediated by the AT1 subtype. The AT1 antagonist losartan, but not the AT2 antagonist PD123319, blocks the increase in ET-1 evoked by ANG II in round cells, while no significant effect on spindle cells is observed.

The influence of adventitia on vascular functions is recognized [13, 27]. Structural changes in the adventitial layer, termed adventitial remodeling, are observed in vascular disease settings, such as hypertension, atherosclerosis [28, 29], restenosis after balloon angioplasty, arteritis, and thoracic aortic dissection [30-32].

ANG II participates in the pathogenesis of cardiovascular and renal diseases by regulating cell growth, causing inflammation and fibrosis. In cultured fibroblasts, ANG II stimulates proliferation and migration [15,33], and this is consistent with our result. In this study, ANG II (100 nM) significantly increases the proliferation and migration of round cells, but no significant influence on spindle cells is observed.

The differentiation of fibroblasts into myofibroblasts is regulated by a complex microenvironment consisting of growth factors, cytokines, adhesion molecules, and extracellular matrix molecules. TGF- $\beta$ is a well-known cytokine capable of inducing transition of a fibroblast into a myofibroblast phenotype by stimulating $\alpha$-SM-actin expression and collagen production [34-36]. Thrombin and ET-1 are also reported to induce differentiation of normal lung fibroblasts into a myofibroblast phenotype [37, 38]. Our previous study demonstrated that ET-1 can induce fibroblast subpopulations into myofibroblast, and the differentiation capability of the subpopulations is significantly different. This study found that ANG II-induced collagen synthesis varied in these two subpopulations. ANG II-induced collagen synthesis could be significantly blocked with Losartan in round cells, yet this effect was not observed in spindle cells. ANG II also had no significant effect on collagen synthesis of two subpopulations with PD123319.

Experimental data indicate that the vascular adventitia is a key regulator of vessel wall structure and function in health and disease [3, 5, 39-41]. It is considered that the vascular adventitia is the most complex compartment in the vessel wall structure and comprises mainly of adventitial fibroblasts [42]. It is also clear that as the sensor, adventitial fibroblasts are first to be activated in response to vascular injury or environmental stress, and then undergoes phenotypic changes [1,43-46]. Our presented data supports the theory that only certain fibroblast subpopulations within a tissue can respond to injury or stress with their specific proliferation and migration capability $[7,47,48]$. These results suggest that both the epithelioid-like and the spindle-like cells may respond to ANG II stimulation in a different manner. The epithelioid-like cells are highly sensitive to ANG II induced preproET-1 and collagen type I mediated through the AT1 receptor. Although the spindle-like cells proliferation rate reaches a peak value with $100 \mathrm{nM}$ ANG II stimulation, ANG II stimulation does not affect the spindle-like cells migration or increase the expressions and secretions of preproET-1 and collagen type I. It may a partly suggest that the epithelioid-like cells are more sensitive than the spindle-like cells in response to vascular injury and stress. Early activation of the epithelioid-like cells may play an important role in regulating vascular wall structure and function through production of chemokines, cytokines and reactive oxygen

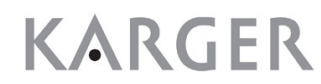


species (ROS), where as spindle cells are mainly involved in the physiological mechanisms of maintaining vascular structure, function and homeostasis.

Beyond these morphologic and functional descriptions of adventitial fibroblasts, no reliable and specific cell marker for the fibroblast has been found to date. It is difficult with current tools to identify precisely fibroblasts in vivo and in vitro. Therefore, to identify fibroblasts, the methods of excluding the possibility of other cell lineages by the lack of specific cell markers (nonleukocyte, nonendothelium, nonsmooth muscle cell, and nonepithelium) are often employed $[1,17]$. Various markers for fibroblasts including discoidin-domain receptor 2, and prolyl-4-hydroxylase, among others, have been utilized to identify the fibroblast [42]. However, all those markers are also expressed in other cell types and are not present in all fibroblasts [1]. Accordingly, we can not specifically reveal the functions of adventitial fibroblast subpopulations in response to vascular pathological and physiological process, especially in vivo. We will therefore further investigate the differences between the epithelioid-like cells and the spindle-like cells through identifying the surface markers in terms of cytoskeletal composition, lipid content and cytokine profile [7, 47, 48]. In hopes of furthering the comprehension and differentiation between fibroblast subpopulations in health and disease.

In conclusion, vascular adventitial fibroblasts of SD rats had two cell subpopulations: round cells and spindle cells. ANG II significantly enhanced cell proliferation and migration, and increased the expression of preproET-1 mRNA in round cell subpopulation. It is suggested that these two cell subpopulations may have different migratory mechanisms in response to stress, injury and cytokines and hormones. Significant differences in phenotype, function and mechanism were observed, which reveals that the two cell subpopulations play different roles in the pathophysiological mechanisms of vascular remodeling and reparative processes.

\section{Acknowledgments}

The authors thank Ryan Boyd and Xue Hui Yang for critical reading of the manuscript. This work was financially supported by the National Natural Science Foundation of China (Grant No. 81473578) and the Hebei Province Natural Science Fund Committee C2009001037 (to S.J.An).

\section{Disclosures Statement}

No conflicts of interest, financial or otherwise, are declared by the author(s).

\section{References}

-1 Stenmark KR, Yeager ME, El Kasmi KC, Nozik-Grayck E, Gerasimovskaya EV, Li M, Riddle SR, Frid MG: The adventitia: essential regulator of vascular wall structure and function. Annu Rev Physiol 2013;75:23-47.

2 Patrick PJ, Gutterman DD: The adventitia: The outs and ins of vascular disease. Cardiovascular Research 2007;75:636-639.

- Wang HD, Ratsep MT, Chapman A, Boyd R: Adventitial fibroblasts in vascular structure and function: The role of oxidative stress and beyond. Can J Physiol Pharmacol 2010;88:177-86.

4 Wu J, Thabet SR, Kirabo A, Trott DW, Saleh MA, Xiao L, Madhur MS, Chen W, Harrison DG: Inflammation and mechanical stretch promote aortic stiffening in hypertension through activation of p38 mitogen-activated protein kinase. Circ Res 2014;114:616-25.

5 Stenmark KR, Frid MG, Yeager M, Li M, Riddle S, McKinsey T, El Kasmi KC: Targeting the adventitial microenvironment in pulmonary hypertension: A potential approach to therapy that considers epigenetic change. Pulm Circ 2012;2:3-14. 
6 Fries KM, Blieden T, Looney RJ, Sempowski GD, Silvera MR, Willis RA, Phipps RP: Evidence of fibroblast heterogeneity and the role of fibroblast subpopulations in fibrosis. Clin Immunol Immunopathol 1994;72:283-292.

7 Phipps RP, Penney DP, Keng P, Quill H, Paxhia A, Derdak S, Felch ME: Characterization of two major populations of lung fibroblasts: distinguishing morphology and discordant display of Thy 1 and class II MHC. Am J Respir Cell Mol Biol 1989;1:65-74.

8 Torry DJ, Richards CD, Podor TJ, Gauldie J: Anchorage-independent colony growth of pulmonary fibroblasts derived from fibrotic human lung tissue. J Clin Invest 1994;93:1525-1532.

-9 Derdak S, Penney DP, Keng P, Felch ME, Brown D, Phipps RP: Differential collagen and fibronectin production by Thy 1+ and Thy 1- lung fibroblast subpopulations. Am J Physiol Lung Cell Mol Physiol 1992;263:L283-L290.

10 Boyd R, Rätsep MT, Ding LL, Wang HD: ETA and ETB receptors are expressed in vascular adventitial fibroblasts. Am J Physiol Heart Circ Physiol 2011;301:H2271-H2278.

-11 Yuen CY, Wong SL, Lau CW, Tsang SY, Xu A, Zhu Z, Ng CF, Yao X, Kong SK, Lee HK, Huang Y: From skeleton to cytoskeleton: osteocalcin transforms vascular fibroblasts to myofibroblasts via angiotensin II and Toll-like receptor 4. Circ Res 2012;111:e55-66.

12 Wang Z, Ren Z, Hu Z, Hu X, Zhang H, Wu H, Zhang M: Angiotensin-II induces phosphorylation of ERK1/2 and promotes aortic adventitial fibroblasts differentiating into myofibroblasts during aortic dissection formation. J Mol Histol 2014;45:401-412.

$\checkmark 13$ Che ZQ, Gao PJ, Shen WL, Fan CL, Liu JJ, Zhu DL: Angiotensin II-stimulated collagen synthesis in aortic adventitial fibroblasts is mediated by connective tissue growth factor. Hypertens Res 2008;31:1233-1240.

- 14 Kim DK, Huh SHL, Hong KP, Park JE, Seo JD, Lee WR: Angiotensin II stimulates proliferation on adventitial fibroblasts cultured from rat aortic explants. J Korean Med Sci 1999;14:487-496.

15 Li L, Zhu DL, Shen WL, Gao PJ: Increased migration of vascular adventitial fibroblasts from spontaneously hypertensive rats. Hypertens Res 2006;29:95-103.

16 Shen WL, Gao PJ, Che ZQ, Ji KD, Yin M, Yan C, Berk BC, Zhu DL: NAD(P)H oxidase derived reactive oxygen species regulate angiotensin-II induced adventitial fibroblast phenotypic differentiation. Biochem Biophys Res Commun 2006;339: 337-343.

17 An SJ, Boyd R, Wang Y, Qiu XF, Wang HD: Endothelin-1 expression in vascular adventitial fibroblasts. Am J Physiol Heart Circ Physiol 2006;290:H700-H708.

18 Oliveira V, Akamine EH, Carvalho MH, Michelini LC, Fortes ZB, Cunha TS, do Carmo Franco M: Influence of Aerobic Training on the Reduced Vasoconstriction to Angiotensin II in Rats Exposed to Intrauterine Growth Restriction: Possible Role of Oxidative Stress and AT2 Receptor of Angiotensin II. PLoS One DOI: 10.1371/0113035.

19 Das M, Dempsey EC, Reeves JT, Stenmark KR: Selective expansion of fibroblast subpopulations from pulmonary artery adventitia in response to hypoxia. Am J Physiol Lung Cell Mol Physiol 2002;282:976986.

20 Desmouliere A, Rubbia-Brandt L, Abdiu A, Walz T, Macieira-Coelho A, Gabbiani G: $\alpha$-Smooth muscle actin is expressed in a subpopulation of cultured and cloned fibroblasts and is modulated by $\lambda$-interferon. Exp Cell Res 1992;201:64-73.

21 Haase I, Hobbs RM, Romero MR, Broad S, Watt FM: A role for mitogen-activated protein kinase activation by integrins in the pathogenesis of psoriasis. J Clin Invest 2001;108:527-536.

22 Sempowski GD, Borrello MA, Blieden TM, Barth RK, Phipps RP: Fibroblast heterogeneity in the healing wound. Wound Repair Regen 1995;3:120-131.

23 Panchenko MV, Farber HW, Korn JH: Induction of heme oxygenase-1 by hypoxia and free radicals in human dermal fibroblasts. Am J Physiol Cell Physiol 2000;278:C92-C101.

24 Benzakour O, Kanthou C, Kanse SM, Scully MF, Kakkar VV, Cooper DN: Evidence for cultured human vascular smooth muscle cell heterogeneity: isolation of clonal cells and study of their growth characteristics. Thromb Haemost 1996;75:854-858.

25 Li G, Chen SJ, Oparil S, Chen YF, Thompson JA: Direct in vivo evidence demonstrating neointimal migration of adventitial fibroblasts after balloon injury of rat carotid arteries. Circulation 2000;101:1362-1365.

-26 Rosenberg RD: Vascular-bed-specific hemostasis and hypercoagulable states: clinical utility of activation peptide assays in predicting thrombotic events in different clinical populations. Thromb Haemost 2001;86:41-50. 
27 Gutterman DD: Adventitia-dependent influences on vascular function. Am J Physiol 1999;277: H1265H1272.

-28 Arribas SM, Hillier C, Gonzalez C, McGrory D, Dominiczak AF, McGrath JC: Cellular aspects of vascular remodeling in hypertension revealed by confocal microscopy. Hypertension 1997;30:1455-1464.

-29 Xu C, Zaring CK, Pannaraj PS, Bassiouny HS, Glagov S: Hypercholesterolemia superimposed by experimental hypertension induces differential distribution of collagen and elastin. Arterioscler Thromb Vasc Biol 2000;20:2566-2572.

-30 Shi Y, Pieniek A, Fard A, O’Brien J, Mannion JD, Zalewaski A: Adventitia remodeling after coronary injury. Circulation 1996;93:340-348.

31 Wilcox JN, Scott NA: Potential role if the adventitia in arteritis and atherosclerosis. Int J Cardiol 1996;54(Suppl): S21-S35.

-32 Wang X, LeMaire SA, Chen L, Shen YH, Gan Y, Bartsch H, Carter SA, Utama B, Ou H, Coselli JS, Wang XL: Increased collagen deposition and elevated expression of connective tissue growth factor in human thoracic aortic dissection. Circulation 2006;114:I200-I205.

-33 Herrmann J, Samee S, Chade A, Porcel MR, Lerman LO, Lerman A: Differential effect of experimental hypertension and hypercholesterolemia on adventitial remodeling. Arterioscler Thromb Vasc Biol 2005;25:447-453.

-34 Gao PJ, Li Y, Sun AJ, Liu JJ, Ji KD, Zhang YZ, Sun WL, Marche P, Zhu DL: Differentiation of vascular myofibroblasts induced by transforming growth factor-beta1 requires the involvement of protein kinase Calpha. J Mol Cell Cardiol 2003;35:1105-1112.

35 Stenmark KR, Davie N, Frid M, Gerasimovskaya E, Das M: Role of the Adventitia in Pulmonary Vascular Remodeling. Physiology 2006;21:134-145.

-36 Steinhorn R, Morin F, Russell J: The adventitia may be a barrier specific to nitric oxide in rabbit pulmonary artery. J Clin Invest 1994;94:1883-1888.

37 Bogatkevich GS, Tourkina E, Abrams CS, Harley RA, Silver RM, Ludwicka-Bradley A: Contractile activity and smooth muscle alpha-actin organization in thrombin-induced human lung myofibroblasts. Am J Physiol Lung Cell Mol Physiol. 2003; 285:L334-L343

- 38 Shi-Wen X, Chen Y, Denton CP, Eastwood M, Renzoni EA, Bou-Gharios G, Pearson JD, Dashwood M, du Bois RM, Black CM, Leask A, Abraham DJ: Endothelin-1 promotes myofibroblast induction through the ETA receptor via a rac/phosphoinositide 3-kinase/Akt-dependent pathway and is essential for the enhanced contractile phenotype of fibrotic fibroblasts. Mol Biol Cell 2004;15:2707-2719.

-39 Majesky MW, Dong XR, Hoglund V, Mahoney WM Jr, Daum G: The adventitia: A dynamic interface containing resident progenitor cells. Arterioscler Thromb Vasc Biol 2011;31:1530-1539.

- 40 Kitamura H, Cambier S, Somanath S, Barker T, Minagawa S, Markovics J, Goodsell A, Publicover J, Reichardt L, Jablons D, Wolters P, Hill A, Marks JD, Lou J, Pittet JF, Gauldie J, Baron JL, Nishimura SL: Mouse and human lung firoblasts regulate dendritic cell traffiing, airway inflmmation, and firosis through integrin alphavbeta8-mediated activation of TGF-beta. J Clin Invest 2011;121:2863-2875.

41 Buckley CD: Why does chronic inflmmation persist: An unexpected role for firoblasts. Immunol Let 2011;138:12-14.

-42 Stenmark KR, Nozik-Grayck E, Gerasimovskaya E, Anwar A, Li M, Riddle S, Frid M: The adventitia: Essential role in pulmonary vascular remodeling. Compr Physiol. 2011;1:141-161.

43 Sorrell JM, Caplan AI: Fibroblasts-a diverse population at the center of it all. Int Rev Cell Mol Biol 2009;276:161-214.

-44 Smith RS, Smith TJ, Blieden TM, Phipps RP: Fibroblasts as sentinel cells. Synthesis of chemokines and regulation of inflmmation. Am J Pathol 1997;151:317-322.

45 Yoshimura K, Shigeura T, Matsumoto D, Sato T, Takaki Y, Aiba-Kojima E, Sato K, Inoue K, Nagase T, Koshima I, Gonda K: Characterization of freshly isolated and cultured cells derived from the fatty and fluid portions of liposuction aspirates. J Cell Physiol 2006; 208:64-76.

46 Phan SH: Fibroblast phenotypes in pulmonary fibrosis. Am J Respir Cell Mol Biol 2003;29:87-92.

-47 Hagood JS, Prabhakaran P, Kumbla P, Salazar L, MacEwen MW, Barker TH, Ortiz LA, Schoeb T, Siegal GP, Alexander CB, Pardo A, Selman M: Loss of fibroblast Thy-1 expression correlates with lung fibrogenesis. Am J Pathol 2005;167:365-379.

48 Phan SH: Fibroblast phenotypes in pulmonary fibrosis. Am J Respir Cell Mol Biol 2003;29:87-92. 